\title{
Pelatihan Implementasi E-Commeree untuk Membuka Peluang Usaha Bagi Masyarakat di Dusun Jetis, Desa Tamantirto
}

\author{
Halim Purnomo1, Titis Wisnu Wijaya2 \\ ${ }^{12}$ Program Studi Doktor Psikologi Islam, Program Pascasarjana, Universitas Muhammadiyah Yogyakarta \\ halimpurnomo@umy.ac.id, titiswisnuwijaya@umy.ac.id \\ DOI: $10.18196 / \mathrm{ppm} .31 .137$
}

\begin{abstract}
ABSTRAK
Tujuan pengabdian ingin memberikan pengetahuan dan keterampilan kepada generasi muda dengan memanfaatkan teknologi e-commerce. Materi yang diberikan adala h aplikasi e-commerce dan cara menggunakan e-commerce sehingga dapat memberikan manfaat dan peluang usaha. Pengabdian ini dilaksanakan di Dusun Jetis, Desa Tamantirto dengan sasaran masyarakat dan generasi muda. Pengabdian ini bekerja sama dengan Kelurahan Dusun Jetis, Desa Tamantirto untuk dapat memaksimalkan pelaksanaan pelatihan. Metode yang digunakan adalah dengan memberikan materi pelatihan melalui presentasi disertai dengan pelatihan implementasi e-commerce. Capaian dari pengabdian ini adalah terlaksananya kegiatan pengabdian sesuai dengan yang diharapkan, yaitu jumlah peserta sebanyak dua puluh pengurus dan anggota Karang Taruna Dusun Jetis RT. oo1 yang dengan antusias mengikuti acara sampai akhir. Peserta mendapat pengetahuan dan keterampilan tentang implementasi e-commerce untuk menangkap peluang usaha.
\end{abstract}

Kata kunci: pelatihan wirausaha online, e-commerce, teknologi, peluang usaha

\section{PENDAhULUAN}

Perkembangan Teknologi Informasi (TI) telah memberi peluang baru bagi kehidupan perekonomian masyarakat. Dengan kemajuan tersebut, tidak ada lagi batasan dalam melakukan perluasan pangsa pasar, khususnya dalam melakukan pemasaran suatu produk atau jasa yang dimiliki. Dusun Jetis, Desa Tamantirto adalah daerah tujuan wisata internasional. Dusun ini merupakan kawasan strategis dalam melakukan bisnis, baik di bidang pariwisata maupun bidang pelengkap dari pariwisata. Namun, tidak banyak masyarakat yang mampu bersaing dalam memanfaatkan peluang tersebut. Perkembangan teknologi, komunikasi, dan komputer mendorong pertumbuhan perekonomian masyarakat yang mengembangkan bisnis secara online. Perkembangan perangkat komunikasi membuat setiap orang yang memiliki smartphone terhubung dengan media internet. Kondisi ini memudah calon pembeli untuk mencari barang yang diinginkan melalui perangkat komunikasi mereka. Dengan demikian, bisnis online ini merupakan sebuah peluang yang sangat menjanjikan untuk dikembangkan.

Masyarakat Dusun Jetis, Desa Tamantirto yang heterogen membuat semakin ketat persaingan dalam berbisnis. Sebagian besar masyarakat lokal Dusun Jetis, Desa Tamantirto 
bergerak di bidang wiraswasta dan bertani. Namun, tidak banyak dari mereka yang telah memanfaatkan teknologi ketika melakukan pemasaran dan penjualan. Akibatnya, mereka sering sekali kalah dalam bersaing di lingkungan sendiri. Pemanfaatan TI, khususnya e-commerce, dalam memperluas pangsa pasar sangat dibutuhkan agar masyarakat Dusun Jetis, Desa Tamantirto mampu bersaing dalam bisnis global saat ini. Dengan memanfaatkan e-commerce, promosi dan penjualan dapat dilakukan ke seluruh dunia tanpa batasan waktu dan biaya yang sangat rendah dibandingkan dengan promosi secara konvensional. Dalam hal ini, penawaran produk/jasa dapat dilakukan sebelum wisatawan datang ke Dusun Jetis, Desa Tamantirto. Selain itu, e-commerce juga dapat menciptakan peluang bisnis baru yang selama ini belum banyak dilakukan, seperti penjualan produk secara online ke seluruh dunia tanpa harus memiliki produk dan toko sendiri terlebih dulu.

Pelatihan Implementasi E-Commerce untuk Membuka Peluang Usaha bagi Masyarakat di Kelurahan Dusun Jetis, Desa Tamantirto diselenggarakan oleh Universitas Muhammadiyah Yogyakarta. Pelatihan ini memberikan pengetahuan dan keterampilan pada masyarakat Kelurahan Dusun Jetis, Desa Tamantirto, khususnya dalam memanfaatkan teknologi khususnya e-commerce, agar mampu bersaing dalam bisnis global. Masyarakat sangat antusias mengikuti kegiatan tersebut. Masyarakat juga berharap agar kegiatan pengabdian seperti ini dapat dilaksanakan secara berkesinambungan dengan pemberian materi yang beragam sehingga dapat meningkatkan kemampuan masyarakat menuju kehidupan yang sejahtera.

\section{TUJUAN DAN MANFAAT}

\section{Tujuan}

Tujuan dari kegiatan pengabdian kepada masyarakat ini adalah untuk memberikan pengetahuan dan keterampilan kepada masyarakat Dusun Jetis, Desa Tamantirto dalam pemanfaatan e-commerce untuk meningkatkan penjualan dan menangkap peluang usaha baru.

\section{Manfaat}

Manfaat yang didapat dari pengabdian kepada masyarakat ini adalah dapat menambah pengetahuan dan kemampuan masyarakat, khususnya generasi muda di Dusun Jetis, Desa Tamantirto, untuk memperluas pemasaran dan menangkap peluang usaha baru sehingga mampu bersaing dalam bisnis global. 


\section{PENGERTIAN E-COMMERCE}

E-commerce merupakan singkatan dari electronic commerce yang secara bahasa diartikan sebagai perdagangan yang berbasis elektronik. Dengan kata lain, e-commerce adalah segala transaksi atau kegiatan bisnis yang dilakukan melalui internet.

\section{Toko online}

Belanja secara online sudah populer di masyarakat, terutama di daerah perkotaan. Saat ini banyak ribuan toko online muncul di Indonesia. Konsumen cukup mengunjungi situs toko online yang dimaksud, mencari daftar barang yang diinginkan dalam katalog, jika cocok langsung klik untuk pembelian, kemudian melakukan transfer uang pembayaran dan barang akan dikirim ke konsumen melalui jasa ekspedisi.

\section{Pembayaran elektronik}

Pembayaran elektronik atau disebut juga dengan e-payment akan membantu orang untuk melakukan transaksi tanpa perlu membawa uang cash ke mana-mana. Dengan demikian, hal ini lebih efisien dan lebih aman.

\section{TARGET IMPLEMENTASI}

\section{E-commerce business to consumer}

Jenis ini adalah bisnis yang dilakukan oleh produsen dalam menjual dan menawarkan produknya kepada konsumen secara online. Jadi, produsen hanya menjual produk atau jasanya, sedangkan pihak konsumen sebagai pemakai atau pembeli.

\section{E-commerce consumer to consumer}

Jenis ini dilakukan oleh antarkonsumen. Pelanggan dari sebuah produsen akan menjual kembali kepada konsumen lainnya.

\section{PELAKSANAAN KEGIATAN}

\section{Pemecahan Masalah}

Pemecahan masalah yang dilakukan dalam pengabdian kepada masyarakat ini adalah

a. Memberikan materi berupa pengetahuan tentang perkembangan internet dan peluang yang ada akibat kemajuan internet yang dapat dimanfaatkan sebagai peluang bisnis baru.

b. Memaparkan contoh-contoh pemasaran dan penjualan yang sukses dengan memanfaatkan internet, khususnya e-commerce. Oleh karena itu, hal ini dapat menjadi contoh usaha dan dapat menjadi perangsang untuk melakukan bisnis melalui internet, khususnya ecommerce. 
c. Memberikan panduan teknik/cara melakukan pemasaran melalui internet, khususnya ecommerce.

d. Memberikan kesempatan kepada peserta pelatihan untuk mengaplikasikan dan menanyakan hal-hal yang belum jelas selama pemaparan materi. Dengan demikian, peserta makin memahami dan mengerti materi yang telah disampaikan.

\section{Khalayak Strategis Sasaran}

Sasaran pelaksanaan kegiatan pengabdian kepada masyarakat ini adalah generasi muda di Dusun Jetis, Desa Tamantirto. Sebagian besar yang hadir dalam pelaksanaan kegiatan ini adalah pemuda-pemudi dan mereka yang telah memiliki usaha, seperti toko pakaian, pembuatan kue dan roti, cendera mata, mebel serta mereka yang tertarik untuk memulai usaha dengan memanfaatkan teknologi internet, khususnya $e$-commerce.

\section{Metode Kegiatan}

Metode yang digunakan dalam kegiatan pengabdian kepada masyarakat ini adalah mempresentasikan materi dan mengimplementasikan materi secara langsung kepada para peserta yang hadir serta menggunakan media lcd proyektor untuk menampilkan slide materi sehigga dapat dilihat dan dimengerti oleh peserta. Setelah pemaparan materi, peserta diberi kesempatan untuk mencoba menggunakan aplikasi e-commerce dan menanyakan sesuatu yang belum paham. Dengan demikian, informasi yang dijelaskan oleh Tim Pengabdian dapat dipahami dengan baik.

\section{HASIL KEGIATAN}

Kegiatan pengabdian kepada masyarakat dengan judul "Pelatihan Implementasi $E$ Commerce untuk Membuka Peluang Usaha bagi Generasi Muda di Dusun Jetis, Desa Tamantirto" dilaksanakan pada hari Selasa, tanggal 28 Januari 2020 di Dusun Jetis, Desa Tamantirto. Para peserta sudah berkumpul pukul 13.00 WIB dan mulai melakukan registrasi. Acara dimulai pukul 13.30 WIB dengan dibuka oleh Ketua RT Jetis, Desa Tamantirto, dan dilanjutkan dengan pemaparan materi.

Penyampaian materi pertama dilakukan oleh Tim Pengabdian kepada masyarakat dengan topik perkembangan internet, manfaat media sosial, dan peluang bisnisnya. Materi metode pemasaran dan penjualan melalui internet/e-commerce disampaikan oleh Tim Pengabdian dan diikuti oleh peserta dengan antusias. Acara ditutup pukul 16.00 WIB dan diakhiri dengan pemberian kenang-kenangan oleh warga Dusun Jetis, Desa Tamantirto kepada Tim Pengabdian. 


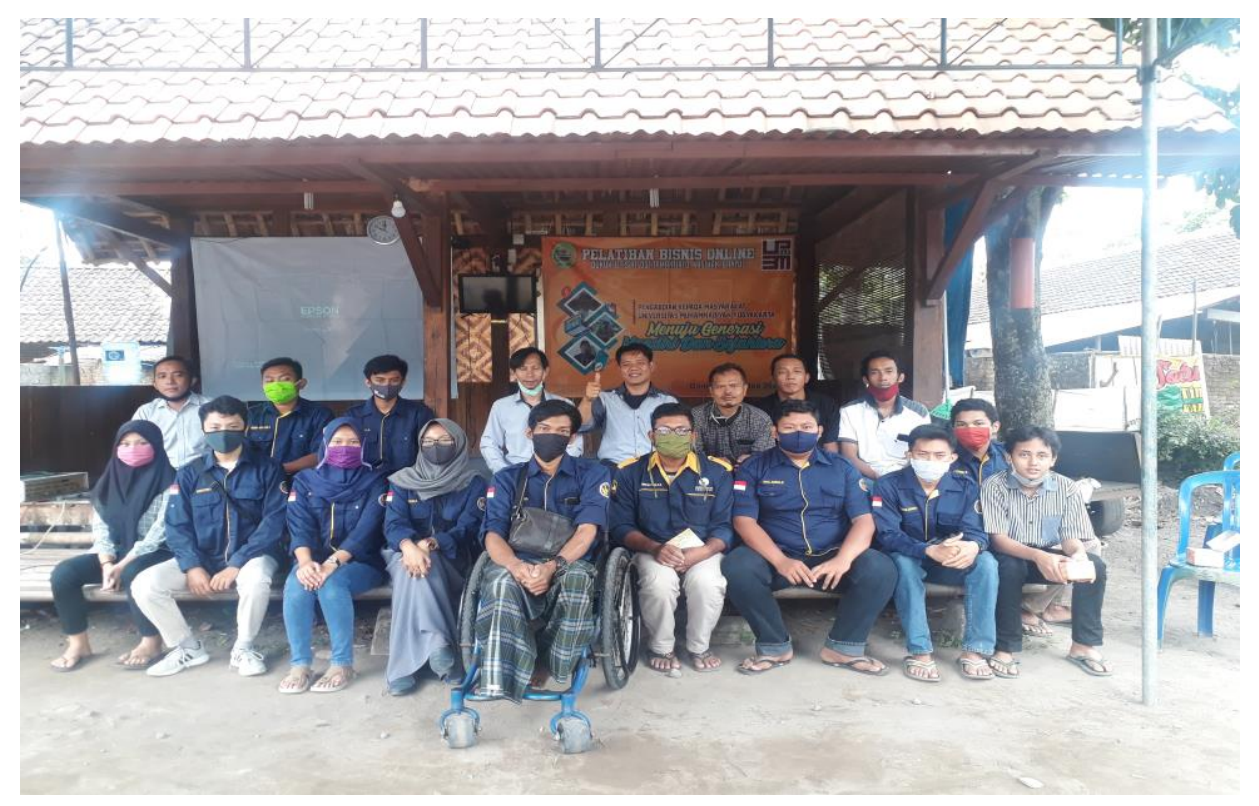

Gambar 4.1 Acara Pelatihan

\section{UGAPAN TERIMA KASIH}

Penulis mengucapkan terima kasih kepada seluruh pihak yang telah membantu pelaksanaan kegiatan pengabdian kepada masyarakat ini, di antaranya

1. Universitas Muhammadiyah Yogyakarta melalui Lembaga Penelitian, Publikasi dan Pengabdian Masyarakat (LP3M) yang telah membiayai pelaksanaan kegiatan pengabdian ini sehingga dapat berjalan dengan baik dan memberikan manfaat kepada masyarakat.

2. Bapak Ketua RT Jetis, Desa Tamantirto yang telah turut serta memberikan kesempatan kepada Tim Pengabdi untuk melaksanakan pengabdian.

3. Rekan dosen, pegawai, mahasiswa Universitas Muhammadiyah Yogyakarta, dan warga Dusun Jetis, Desa Tamantirto yang telah banyak membantu hingga terlaksananya kegiatan pengabdian ini.

4. Seluruh pihak yang tidak dapat penulis sebutkan satu per satu yang telah membantu pelaksanaan kegiatan.

\section{DAFTAR PUSTAKA}

Ahmadi, C. dan Hermawan, D. (2014), E-business dan E-commerce, Andi Offset, Yogyakarta.

Awais, Muhammad dan Samin, Tanzila, "Advanced SWOT Analysis of E-Commerce", International Journal of Computer Science Issues, Vol. 9, Issue 2, No 2, March 2012. 
E-commerce: business. technology. society., 2/E: Kenneth C. Laudon, New York University: Jeffrey Travis, Nacimiento Software Corporation, Austin, Texas.

Irnawati, Dewi, "Pemanfaatan E-Commerce Dalam Dunia Bisnis, Jurnal Ilmiah Orasi Bisnis, Edisi Ke-VI, November 2011.

Madncoms, (2011), Sukses Membangun Toko Online dengan E-commerce, Andi Offset, Yogyakarta.

Priyanto, Cinky. (2020), Pengembangan Digital Marketing di Era 4.0. Logine. Yogyakarta.

Purbo, O. W dan Daniel, S., (2000), Membangun Web E-Commerce, Elex Media. Komputindo Waloeyo (2012), Cloud Computing, Andi Offset, Yogyakarta. 